\title{
Microscopical studies on the hemocytes of bivalves and their phagocytic interaction with selected bacteria
}

\author{
G. E. Rodrick \& S. A. Ulrich \\ University of South Florida, College of Public Health; \\ 13301 North 30th Street, Tampa, Florida 33612, USA
}

\begin{abstract}
Hemocytes represent one of the most important defense mechanisms against foreign material in Mollusca. The morphology, hematological parameters and behaviour of hemolymph cells were studied in the southern quahog Mercenaria campechiensis, the eastern oyster Crassostrea virginica, and the blood ark Anadara ovalis challenged with the bacteria Vibrio vulnificus and $V$. anguillarum. Two general classes of hemocytes (granular and agranular) exist in $C$. virginica and $M$. campechiensis. In contrast, $A$. ovalis possesses 3 general classes (granular, agranular and erythrocytes). Three types of granules were identified by light microscopy. When hemolymph cells were studied by transmission electron microscopy, the cytoplasm of hemolymph cells was noted to contain many organelles, including electron dense granules. Both agranular and granular hemolymph cells were capable of colchicine-sensitive pseudopodial movement and spreading. The results indicate that marine bivalves possess hemolymph blood cells which may play a role in the internal defense paralleling mammalian phagocytes. The morphology of these cells, as determined by light, scanning and transmission electron microscopy, showed some similarity to mammalianmononuclear phagocytes. The sub-cellular events of molluscan hemocyte phagocytosis of $V$. vulnificus and $V$, anguillarum were studied by both scanning and transmission electron microscopy. The role of these cells and the factors which govern their behavior are of economic and public health importance.
\end{abstract}

\section{INTRODUCTION}

Filter-feeding shellfish are well known for their ability to internally concentrate both abiotic and biotic materials at concentrations greater than their ambient sea water (Cheng, 1967). The major molluscan defense mechanisms against such invading foreign material is primarily cellular and is closely associated with the hemolymph blood cells (Cheng, 1967). These molluscan hemolymph cells have been demonstrated to perform numerous functions, including: pinocytosis, phagocytosis and encapsulation of abiotic as well as biotic foreign materials (Cheng, 1967; Cheng \& Rifkin, 1970). In this regard molluscan hemolymph cells are very similar to mammalian mononuclear phagocytes. Because of these properties, the hemolymph cells may play an important role in disposal of such invading materials.

Therefore, three marine bivalves, the southern quahog - Mercenaria campechiensis; the eastern oyster - Crassostrea virginica and the blood ark - Anadara ovalis, have been examined for morphology, hematologic parameters, selected hydrolytic enzyme activities and phagocytic behavior of hemolymph cells. 


\section{MATERIALS AND METHODS}

Bi ological materials. The eastern oyster (Crassostrea virginica), the southern quahog (Mercenaria campechiensis) and the blood ark (Anadara ovalis) were collected in Tampa Bay at Tampa, Florida.

All shellfish were maintained at least 10 days in recirculating seawater tanks at $25 \%$ salinity and $20 \mathrm{C}$ using established techniques (Rodrick \& Cheng, 1974).

Collection of he moly $\mathrm{m} p \mathrm{~h}$. In all three molluscs, hemolymph samples were collected from the anterior adductor muscle sinus by using endotoxin free hypodermic needles and syringes (Feng et al., 1971).

Preparation of hemolymph. One half milliliter of freshly drawn hemolymph was immediately discharged on to the center of an endotoxin free glass microscope slide and placed in a humidity dish and the hemocytes allowed to spread undisturbed. At pre-determined timed intervals $(0,5,10,15$ and $20 \mathrm{~min})$ spreading cells were fixed for either light microscopy (Guida \& Cheng, 1980); transmission electron microscopy (Cheng \& Cali, 1974) and scanning electron microscopy (Cheng \& Foley, 1972).

In vitro phag ocy tic studies. Cultures of Vibrio anguillarum, V. vulnificus. Escherichia coli, Bacillus megaterium and Staphylococcus aureus were grown, harvested, washed and counted using established techniques (Cheng, 1975; Tamplin et al., 1983).

All bacteria were suspended in $0.01 \mathrm{M}$ Sorensen's buffer, pH 7.2 and added to hemocyte preparations from Mercenaria campechiensis, Crassostrea virginica and Anadara ovalis at a ratio of at least 2:1.

The bacteria-hemocyte preparations were incubated at three different temperatures $\left(4^{\circ}, 22^{\circ}\right.$ and $\left.37^{\circ} \mathrm{C}\right)$. In addition, identical experiments were performed with hemocytes reconstituted in (1) sterile sea water (millosmomolles), (2) serum heated at $56^{\circ} \mathrm{C}$ for 30 minutes; (3) serum treated with $1 \mathrm{mg}$ trypsin (units); and (4) serum with 500 milligrams of colchicine. The bacteria-hemocyte phagocytosis was stopped at pre-determined timed intervals of $0,30,60$ and 90 minutes with either Farley's fixative or $1 \%$ glutaraldehyde ( $970 \mathrm{mOsm}$ ) at room temperature for one hour then as described by Guida \& Cheng (1980).

The mean number of bacteria associated with the two types of hemocytes, granulocytes and agranulocytes, was determined by recording the number of bacteria associated with the first ten cells of each type observed in each preparation, cells stated to be in association with bacteria include those in the first and second stages of phagocytosis (e.g. with bacterial adhering to their surfaces, as well as those within intracellular phagosomes).

Since differences in cell surface areas of spread hemolymph cells could theoretically affect the number of bacteria that make contact with the cell over a given time period, consideration was given to the determination of the mean surface area of each cell type exposed to bacterial suspensions. Approximate mean surface areas for granulocytes and agranulocytes were computed from the dimensions of ten cells of each cell type chosen at random.

Enzyme assays. All enzyme assays were made on cell pellet resulting from centrifugation of fresh hemolymph at $3000 \mathrm{~g}$.

For the determination of lysozyme activity, a modification of the method of Shugar 
(1952) was employed. This involved using a $0.1 \mathrm{M}$ glycylglycine buffer at $\mathrm{pH} 5.5$ and 0.2 $\mathrm{mg} / \mathrm{ml}$ of Micrococcus lysodeikticus as substrate. The activities of acid and alkaline phosphatases were ascertained by monitoring the hydrolysis of sodium-p-nitrophenylphosphate spectrophotometrically at $405 \mathrm{m \mu}$ and $25^{\circ} \mathrm{C}$ at $\mathrm{pH} 4.8$ and 10.5 respectively (Shugar, 1952; Fishman \& Lerner, 1953).

The method of Fishman et al. (1948) was used to detect the activity of $\beta$-glucuronidase. This involved employing phenolphthalein as the substrate and the reaction was moderated as $57^{\circ} \mathrm{C}$ and $\mathrm{pH} 6.8$. One unit of $\beta$-glucuronidase activity is that amount required to cleave $1 \mathrm{mmol}$ of phenolphthalein glucuronic acid $/ \mathrm{min}$ at $57^{\circ} \mathrm{C}$.

Amylase activity was assayed spectrophotometrically by the method of Somogyi (1938). One international unit of this enzyme is defined as that amount that will cause the formation of a reducing capacity equivalent to $1 \mathrm{mg}$ of glucose in $30 \mathrm{~min}$ at $\mathrm{pH} 6.8$ and $40^{\circ} \mathrm{C}$. The lipase activity was measured by titrating the hydrolysis of an emulsion of olive oil and 1 sigma-Tietz unit of activity is equal to $1 \mathrm{mmol}$ of acid produced $/ \mathrm{min}$ at $25^{\circ} \mathrm{C}$ and $\mathrm{pH} 7.5$ (Tietz et al. 1959).

The activities of GOT and GPT, expressed as Sigma-Frankel units/mg protein, were assayed spectrophotometrically at $505 \mathrm{mU}$ by the method of Reitman \& Frankel (1957). The protein contents of all the enzyme solutions were ascertained by the method of Lowry et al., (1951). Glycogen was determined by the method of Montgomery (1957).

Granule is olation. Three mols of fresh hemolymph were collected by use of a plastic syringe containing $3 \mathrm{mls}$ of a $5 \%$ solution of ethylene diamine tetraacetate disodium (EDTA), pH 7.0. The resulting mixture of EDTA-hemolymph mixed thoroughly then discharged through a cellulose nitrate membrane ( $25 \mathrm{~mm}$, pore size 8 microns).

The resulting filtrate was then layered over three layers of glycerin $(33 \%, 67 \%$ and $100 \%$ ), then centrifuged at $58,000 \times \mathrm{g}$ for $45 \mathrm{~min}$.

The centrifuged filtrate was then fractionated into $1 \mathrm{ml}$ samples and assayed for acid phosphate (Shugar, 1952). Fractions exhibiting high acid phosphates activity were microscopically inspected for the presence of hemocyte granules.

\section{RESULTS}

\section{Hemolymph cell composition}

When the three molluscs were examined to determine the cellular composition, Mercenaria campechiensis and Crassostrea virginica were very similar; however, Anadara ovalis differed significantly, since it contained erythrocytes (Table 1). All of the molluscs contained both agranulocytic and granulocytic cells. Transmission electron microscopy of hemocytes revealed a prominent nucleus, the presence of numerous cytoplasmic organelles and numerous electron dense granules (Figs 2 and 3). In both $M$. campechiensis and $C$. virginica granulocytes were slightly higher in concentration than agranulocytes. However, in $A$. ovalis the agranulocytes outnumbered granulocytes 2:1. The total number of non-erythrocytes in the Blood Ark was approximately equivalent to that seen in the two other molluscs. 


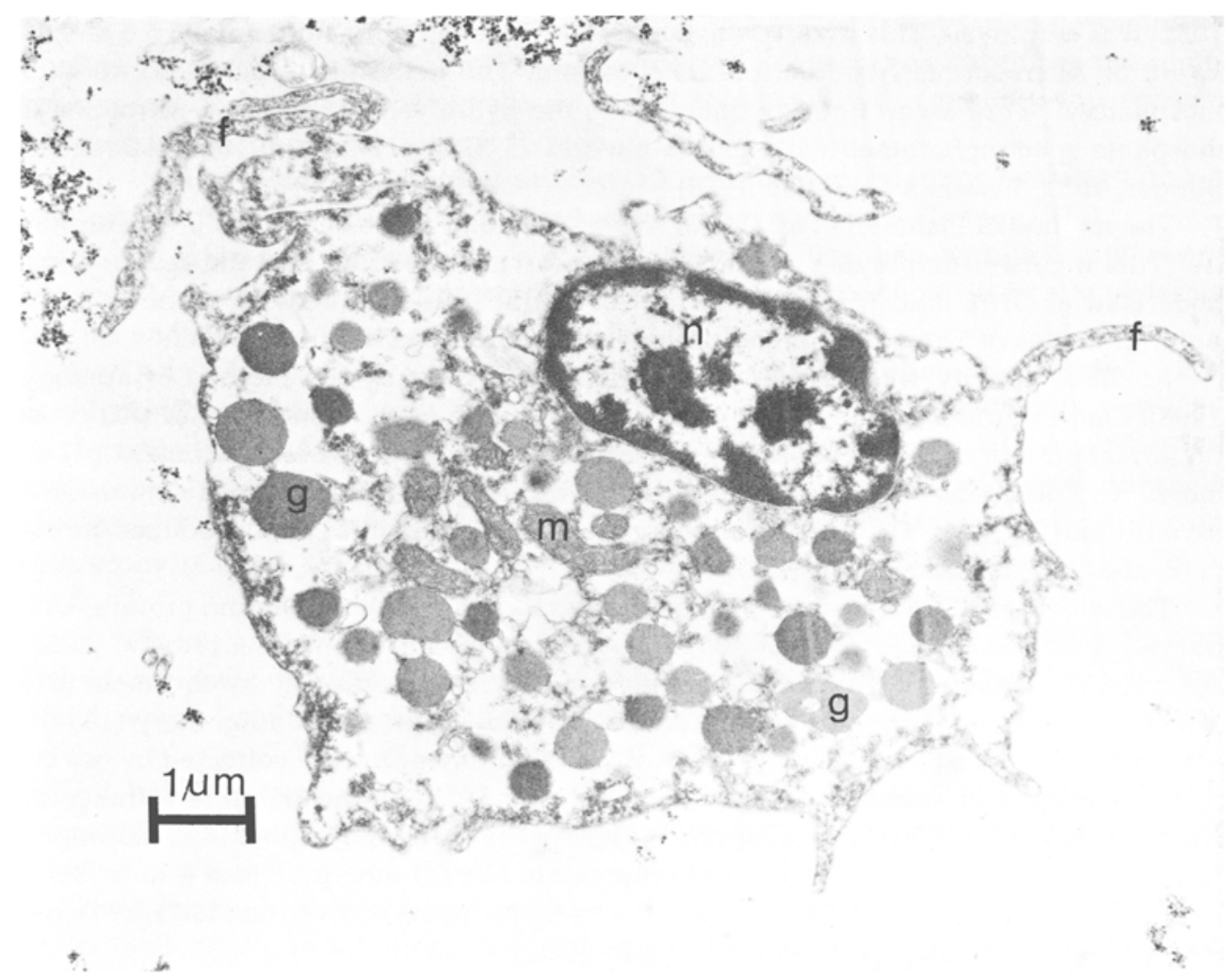

Fig. 1. Electron micrograph of Mercenaria campechiensis granulocyte with prominent nucleus (n), mitochondria (m), electrondense granules $(\mathrm{g})$ and filapodia $(\mathrm{f})$

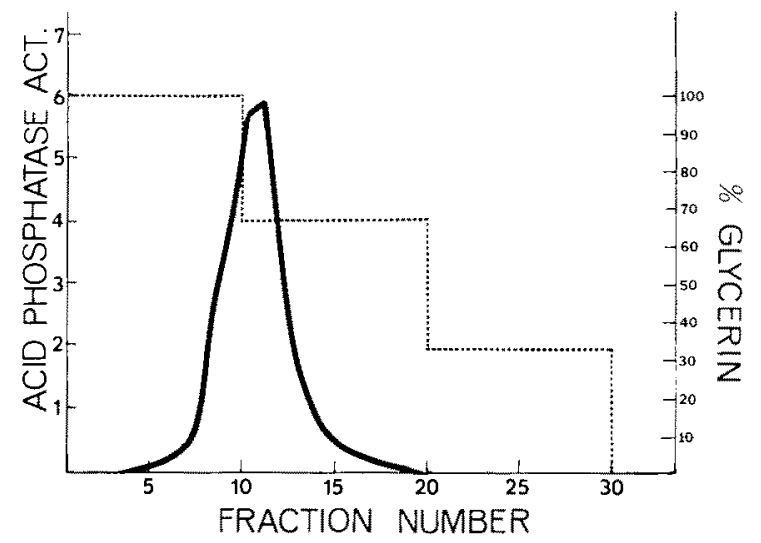

Fig. 2. Fractionation of Mercenaria campechiensis $3000 \mathrm{mg}$ cell pellet using a glycerin gradient and acid phosphatase activity as a marker. Solid black denotes acid phosphatase activity and dashed line denotes percent glycerin 


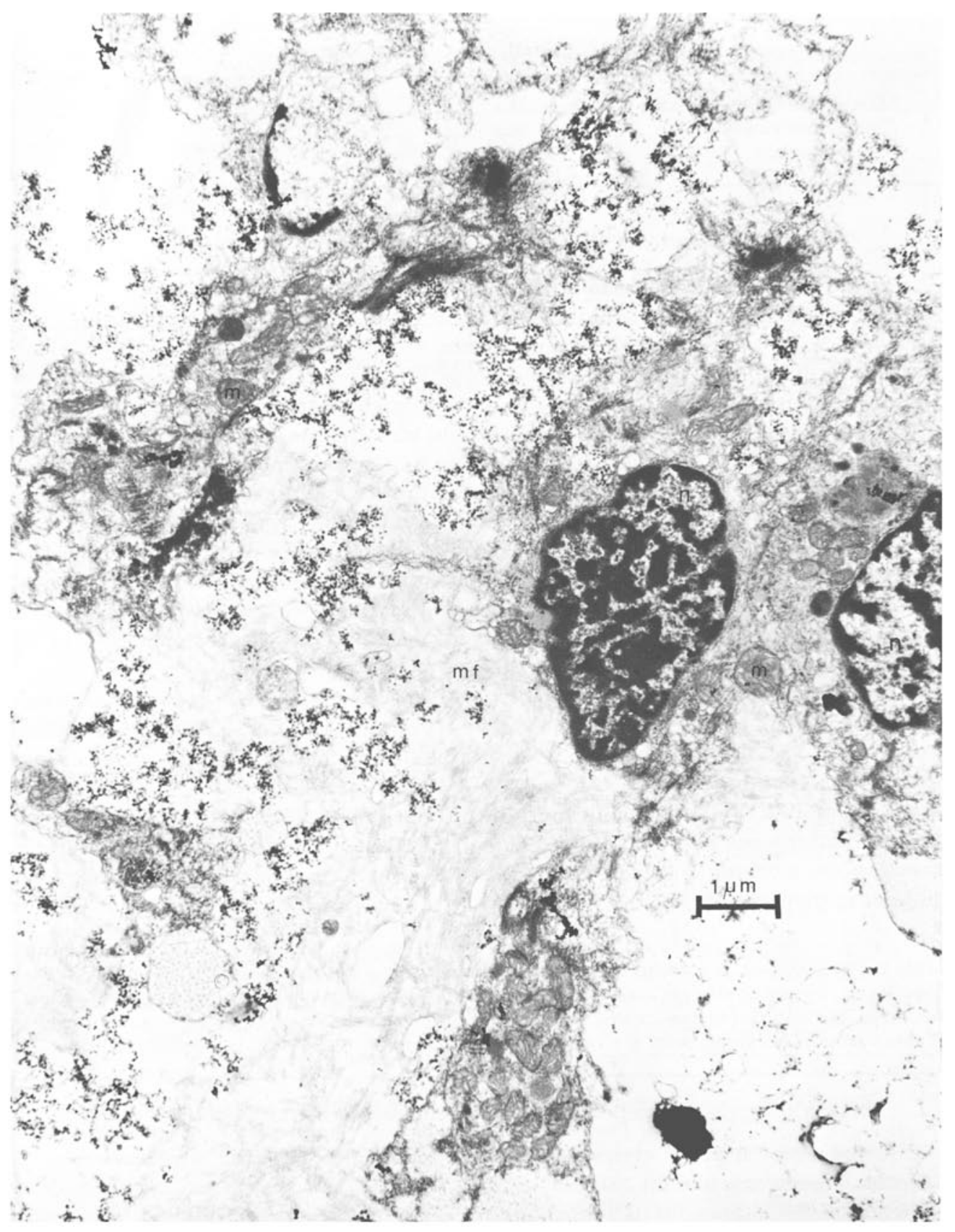

Fig. 3. Electron micrograph of a granulocyte after 60 min exposure to Bacillus megaterium; $\mathrm{mf}=$ microfilaments, $\mathrm{m}=$ mitochondria, $\mathrm{g}=$ glycogen, $\mathrm{n}=$ nucleus 
Table 1. Hemolymph cell composition of Mercenaria campechiensis, Crassostrea virginica and Anadara ovalis. All values are expressed as percentages

\begin{tabular}{|lccc|}
\hline \multicolumn{1}{c}{ Species } & Granulocytes & Agranulocytes & Erythrocytes \\
\hline Mercenaria campechiensis & 58.4 & 41.6 & 0 \\
Crassostrea virginica & 54.6 & 45.4 & 0 \\
Anadara ovalis & 1.6 & 3.3 & 95.1 \\
\hline
\end{tabular}

\section{Phagocytosis of bacteria by Crassostrea virginica}

When $C$. virginica was examined for its ability to phagocytose four strains of bacteria, results were dependent on the presence of serum in the medium (Table 2). In the absence of serum Escherichia coli were engulfed more efficiently than either Staphylococcus aureus, Bacillus megaterium or Vibrio anguillarum. However, when the serum was present, phagocytosis was 3-10 times greater depending upon the bacteria employed. When hemocytes were reconstituted with heat treated serum, phagocytosis was depressed. This effect is most likely due to a serum factor which was labile to heating at $57^{\circ} \mathrm{C}$ for $30 \mathrm{~min}$. Heating abrogated the serum effects and actually reduced phagocytosis to levels equal to or lower than those seen in serum-free medium.

In addition, incubation of cells for $60 \mathrm{~min}$ in the presence of $500 \mathrm{mg}$ of colchicine reduced phagocytosis to levels equal to or lower than that seen with serum-free media.

The effects of three temperatures upon phagocytosis was tested. The increase of temperature increased the number of bacteria associated with the hemocytes of $M$. campechiensis and C. virginica (Table 3).

It was also noted that during in vivo exposure of $M$. campechiensis, $C$, virginica, and $A$. ovalis to $E$. coli and $V$. anguillarum and that glycogen concentrations increased in the hemolymph. Specifically, glycogen levels in the hemolymph of $M$. campechiensis rose from $27.8 \pm 1.3 \mu \mathrm{g} / \mathrm{ml}$ to $39.7 \pm 1.2 \mu \mathrm{g} / \mathrm{ml}$ in one hour after exposure to $E$. coli and $V$. anguillarum. In a similar fashion $C$. virginica and $A$. ovalis hemolymph glycogen levels increased after a one hour exposure to $E$. coli and $V$. anguillarum (Table 4). In addition, transmission electron microscopy revealed the presence of endophagocytic vesicles containing glycogen (Fig. 3).

Table 2. Phagocytosis of Bacillus megaterium, Escherichia coli, Staphylococcus aureus and Vibrio anguillarum by hemocytes of Crassostrea virginica in the presence of normal serum, seawater, heattreated serum and colchicine-treated cells. Values are the mean number of bacterial cells associated with hemolymph cells of Crassostrea virginica in vitro at $25^{\circ} \mathrm{C}$ for one hour $(\mathrm{n}=80)$

\begin{tabular}{|lcccc|}
\hline \multicolumn{1}{|c}{ Bacteria } & $\begin{array}{c}\text { With serum } \\
\text { fraction }\end{array}$ & $\begin{array}{c}\text { Without serum } \\
\text { fraction }\end{array}$ & $\begin{array}{c}\text { Heat-treated } \\
\text { serum }\end{array}$ & $\begin{array}{c}\text { Colchicine- } \\
\text { treated cells }\end{array}$ \\
\hline Bacillus megaterium & 9.48 & 1.01 & 0.09 & 0.1 \\
Escherichia coli & 10.51 & 3.54 & 2.01 & 0.4 \\
Staphylococcus aureus & 10.44 & 1.84 & 1.04 & 0.6 \\
Vibrio anguillarum & 6.51 & 1.06 & 0.51 & 0.6 \\
\hline
\end{tabular}


Table 3. Differential counts of spread, fixed and stained hemocytes of Mercenaria campechiensis and Crassostrea virginica exposed to viable Vibrio vulnificus and Bacillus megaterium at three different temperatures

\begin{tabular}{|c|c|c|c|c|c|c|c|}
\hline \multirow[t]{2}{*}{ Species } & \multirow[t]{2}{*}{ Control } & \multicolumn{3}{|c|}{ Vibrio vulnificus } & \multicolumn{3}{|c|}{ Bacillus megaterium } \\
\hline & & $4^{\circ} \mathrm{C}$ & $22^{\circ} \mathrm{C}$ & $37^{\circ} \mathrm{C}$ & $4^{\circ} \mathrm{C}$ & $22^{\circ} \mathrm{C}$ & $37^{\circ} \mathrm{C}$ \\
\hline \multicolumn{8}{|c|}{ Mercenaria campechiensis } \\
\hline granulocytes & $<1$ & 4.5 & 6.0 & 11.1 & 4.4 & 6.3 & 7.5 \\
\hline agranulocytes & $<1$ & $<1$ & $<1$ & $<1$ & & $<1$ & $<1$ \\
\hline \multicolumn{8}{|c|}{ Crassostrea virginica } \\
\hline granulocytes & $<1$ & 3.9 & 6.4 & 10.3 & 3.6 & 6.1 & 8.4 \\
\hline agranulocytes & $<1$ & $<1$ & $<1$ & $<1$ & $<1$ & $<1$ & $<1$ \\
\hline
\end{tabular}

Table 4. Hemolymph glycogen concentrations ( $\mu \mathrm{g} / \mathrm{ml}$ ) before (above) and after $1 \mathrm{~h}$ (below) of in vivo exposure to Escherichia coli and Vibrio anguillarum

\begin{tabular}{|ccc|}
\hline Species & Escherichia coli & Vibrio anguillarum \\
\hline Mercenaria campechiensis & $\frac{27.8 \pm 1.3}{39.7 \pm 1.2}$ & $\frac{27.4 \pm 1.1}{38.8 \pm 1.4}$ \\
Crassostrea virginica & $\frac{21.4 \pm 1.1}{32.3 \pm 1.6}$ & $\frac{22.6 \pm 1.1}{33.1 \pm 0.4}$ \\
Anadara ovalis & $\frac{11.3 \pm 0.6}{14.1 \pm 1.2}$ & $\frac{10.4 \pm 1.1}{14.4 \pm 1.4}$ \\
\hline
\end{tabular}

Table 5. Specific activities of selected hydrolytic enzymes in the $3000 \mathrm{xg}$ cell pellet of hemolymph from Mercenaria campechiensis, Crassostrea virginica and Anadara ovalis

\begin{tabular}{|lccc|}
\hline \multicolumn{1}{|c}{ Enzyme } & $\begin{array}{c}\text { Mercenaria } \\
\text { campechiensis }\end{array}$ & $\begin{array}{c}\text { Crassostrea } \\
\text { virginica }\end{array}$ & $\begin{array}{c}\text { Anadara } \\
\text { ovalis }\end{array}$ \\
\hline Lysozyme (AOD/mg protein) & 38.75 & 31.75 & 4.11 \\
B-glucoronidase (Sigma U/mg protein) & 15.12 & 17.45 & 2.84 \\
Acid Phosphatase (mU/mg protein) & 15.16 & 14.61 & 3.11 \\
Alkaline Phosphatase (mU/mg protein) & 8.16 & 7.28 & 2.17 \\
Lipase (Sigma-Tietz U/mg protein) & 0.03 & 0.02 & 19.38 \\
SGOT (Sigma-Frankel U/mg protein) & 82.48 & 84.6 & 21.41 \\
SGPT (Sigma-Frankel U/mg protein) & 71.41 & 75.48 & \\
\hline
\end{tabular}

Hydrolytic enzymes associated with mollusc hemolymph cells

Lysosomes of mammalian phagocytes are known to contain large amounts of hydrolytic enzymes, thus the molluscan cells were examined for several enzymes commonly found in mammalian cells. Table 5 indicates that substantial levels of many of the hydrolytic enzymes are present in $M$. compechiensis and $C$. virginica, while levels in A. ovalis were considerably lower. Lipases were present only in trace amounts. Cell 
fractionation studies on $M$. campechiensis $3000 \times \mathrm{g}$ cell pellet using acid phosphatase activity as a marker revealed a single peak of activity (Fig. 1). Light microscope examination of the peak acid phosphatase activity revealed the presence of numerous granules.

\section{DISCUSSION}

Several attempts have been made to describe the hemolymph cells of various marine shellfish (Takatsuk, 1934; Galtsoff, 1964; Feng et al., 1971; Ruddell, 1971; Foley \& Cheng, 1972) and to study their phagocytic activity towards various bacteria (Foley \& Cheng, 1972; Cheng \& Cali, 1974; Cheng, 1975; Hardy et al., 1977). In general, two distinct classes of cells exist and they are granular and agranular hemocytes. In the case of Crassostrea virginica and Mercenaria campechiensis, the presence of agranular hemocytes and granular hemocytes with refractile granules reported in this study are in agreement with those of Feng et al., (1971) and Foley \& Cheng (1972).

Relative to the function of hemocytes of $M$. campechiensis, $C$. virginica and Anadara ovalis the granular cells seem to be more highly phagocytic. These findings are consistent with results published for $C$. virginica by Galtsoff (1964) and Cheng \& Rifkin (1970).

It is of interest to note that several multinucleated cells were occasionally observed in both $M$. campechiensis and $C$. virginica preparations as reported by Sparks \& Pauley (1964) in moribund Crassostrea gigas. Such multinucleated hemocytes may occur under certain pathological conditions (Cheng \& Galloway, 1970).

The factors required for $C$. virginica hemocyte phagocytosis of bacteria are not well known. In the absence of humoral factors (serum free) phagocytosis is reduced to a low level but not eliminated. This low level phagocytosis may be due to specific recognition factors on the hemocyte or to non-specific, physico-chemical mechanisms as suggested by Hardy et al., 1977.

Hemocytes reconstituted in heat-treated serum phagocytosed bacteria at low levels and is indicative that the factor(s) responsible for phagocytosis is/are heat labile. It was also noted that colchicine treated $C$. virginica hemocytes phagocytosed bacteria at a lower level. This may indicate that the microtubules play an important role in the phagocytosis of foreign material.

The fate of the phagocytosed material is of interest. Glycogen concentration increased significantly in the hemocytes after $60 \mathrm{~min}$ of bacterial exposure. Transmission electron microscopy revealed numerous glycogen rosettes in numerous phagocytic vesicles. These results agree with previous investigations by Cheng \& Cali (1974) and Cheng \& Rudo (1976).

It is well known that of the hydrolytic enzymes studied, $\beta$-glucuronidase, acid and alkaline phosphatase, lysozyme and lipase occur in lysosomes (Tappel et al., 1969). Therefore, it is not unusual that high specific hydrolytic enzyme activities were found in the $3000 \times \mathrm{g}$ hemocyte pellet and high acid phosphatase activity associated with isolated granules.

In addition, two transaminases, GPT and GOT were associated with the $3000 \times \mathrm{g}$ hemocyte pellet. The occurrence of transaminases in molluscs are well known (Read, 1962; Awapara \& Campbell, 1964; Goddard \& Martin, 1966) however, their origin remains unknown. 
Fluctuations occurred in the specific activities of all the enzymes assayed. These fluctuations may be explained because the open circulatory system is in direct communication with the exterior (Cheng, 1963; Galtsoff, 1964; Rodrick, 1979).

In summary, more detailed studies involving the molluscan hemocytes are needed to elucidate the mechanisms that may affect or influence the susceptibility or non-susceptibility of molluscs to invading foreign material. Such information is essential if rational approaches are to be taken to prevent microbial diseases that weaken or destroy economically important shellfish (Cheng, 1975).

\section{LITERATURE CITED}

Awapara, J. \& Campbell, J. S., 1964. Utilization of $\mathrm{C}^{14} \mathrm{O}_{2}$ for the formation of some amino acids in three invertebrates. - Comp. Biochem. Physiol. 11, 231-235.

Cheng, T. C., 1963. Biochemical requirements of larval trematodes. - Ann. N. Y. Acad. Sci. 113, 289-320.

Cheng, T. C., 1967. Marine molluscs as hosts for symbiosis: with review of known parasites of commercially important species. - Adv. mar. Biol. 5, 1-424.

Cheng, T. C., 1975. Functional morphology and biochemistry of molluscan phagocytes. - Ann. N. Y. Acad. Sci. 266, 343-379.

Cheng, T. C. \& Cali, A., 1974. An electron microscope study of the fate of bacteria phagocytized by granulocytes of Crassostrea virginica. - Contemp. Top. Immunobiol. 4, 25-35.

Cheng, T. C. \& Foley, D. A., 1972. A scanning electron microscope study of the cytoplasmic granules of Crassostrea virginica granulocytes. - J. Invertebr. Pathol. 20, 372-374.

Cheng, T. C. \& Galloway, P. C., 1970. Transplantation immunity in mollusks: the histoincompatibility of Helisoma duryi normale with allografts and xenografts. - J. Invertebr. Pathol. 15, 177-192.

Cheng, T. C. \& Rifkin, E., 1970. Cellular reactions in marine molluscs in response to helminth parasitism. In: A symposium on diseases of fishes and shellfishes. Ed. by S. F. Snieszko. Washington, 443-496. (Spec. Publ. Am. Fish. Soc. 5.)

Cheng, T. C. \& Rudo, B. M., 1976. Distribution of glycogen resulting from degradation of ${ }^{14} \mathrm{C}-$ labelled bacteria in the American oyster, Crassostrea virginica. - J. Invertebr. Pathol. 27, 259-262.

Feng, S. Y., Feng, J. S., Burke C. N. \& Khairallah, L. H., 1971. Light and electron microscopy of the leucocytes of Crassostrea virginica (Mollusca: Pelecypoda). - Z. Zellforsch. mikrosk. Anat. 120, 222-245.

Fishman, W. H. \& Lerner, F, 1953. A method of estimating serum acid phosphatase of prostatic origin. - J. biol. Chem. 200, 89-97.

Fishman, W. H., Springer, B. \& Brunetti, R., 1948. Application of an improved glucuronidase assay method to the study of human blood $\beta$-glucuronidase. $-J$. biol. Chem. 173, 449-456.

Foley, D. A. \& Cheng, T. C., 1972. Interaction of molluscs and foreign substances: The morphology and behavior of hemolymph cells of the American oyster, Crassostrea virginica, in vitro. - J. Invertebr. Pathol. 19, 383-394.

Galtsoff, P. S., 1964. The American oyster, Crassostrea virginica. Gmelin. - Fish. Bull. U.S. 64, $1-480$.

Goddard, C. K. \& Martin, A. W., 1966. Carbohydrate metabolism. In: Physiology of mollusca. Ed. by K. M. Wilbur \& C. M. Yonge. Acad. Press, New York, 1, 275-308.

Guida, V. G. \& Cheng, T. C., 1980. Lead hematoxylin-basic fuchsin: a new stain for molluscan hemocytes. - Trans. Am. microsc. Soc. 99, 135-140.

Hardy, S. W., Fletcher, T. C. \& Olafsen, J. A., 1977. Aspects of cellular and humoral defence mechanisms in the Pacific oyster, Crassostrea gigas. In: Developmental immunbiology. Ed. by J. B. Solomon \& J. D. Horton. Elsevier/North-Holland Biomedical Press, Amsterdam, 59-66.

Lowry, O. H., Rosebrough, H. J., Farr, A. L. \& Randall, R. I., 1951, Protein measurement with folin phenol reagent. - J. biol. Chem. 193, 265-275.

Montgomery, R., 1957. Determination of glycogen. - Archs Biochem. Biophys. 67, 378-386. 
Read, K. R. H., 1962. Transamination in certain tissue homogenates of the bivalved molluscs (Mytilus edulis L. and Modiolus modiolus L.). - Comp. Biochem. Physiol. 7, 15-22.

Reitman, S. \& Frankel, S., 1957. A colorimetric method for the determination of serum glutamic oxalacetic and glutamic pyruvic transaminase. - Am. J. clin. Path. 28, 56-63.

Rodrick, G. E., 1979. Selected enzyme activities in Mya arenaria hemolymph. - Comp. Biochem. Physiol. 62B, 313-316.

Rodrick, G. E. \& Cheng, T. C., 1974. Kinetic properties of lysozyme from the hemolymph of Crassostrea virginica. - J. Invertebr. Pathol. 24, 41-48.

Ruddell, C. L., 1971. The fine structure of oyster agranular amebocytes from regenerating mantle wounds in the Pacific oyster, Crassostrea gigas. - J. Invertebr. Pathol. 18, 260-268.

Shugar, D., 1952. Measurement of lysozyme activity and the ultraviolet inactivation of lysozyme. Biochim. biophys. Acta 8, 302-308.

Somogyi, M., 1938. Micromethods for the estimation of diatase, - J. biol. Chem. 125, 399-414.

Sparks, A. K. \& Pauley, G. B., 1964. Studies of the normal postmortem changes in the oyster, Crassostrea gigas (Thunberg). - J. Invertebr. Pathol. 6, 78-101.

Takatsuki, S. A., 1934. On the nature and functions of the amebocytes of Ostrea edulis. $-\mathrm{Q}$. Jl.z. microsc. Sci. $76,379-431$.

Tamplin, M., Rodrick, G. E., Blake, N. J. \& Cuba, T, 1983. The isolation and characterization of Vibrio vulnificus from two Florida estuaries. - Appl. environ. Microbiol. 44, 1466-1469.

Tappel, A. L., 1969. Lysosomal enzymes and other components. In: Lysosomes in biology and pathology. Ed. by J. T. Dingle \& H. B. Bell. North Holland Publ., Amsterdam, 2, $207-244$.

Tietz, N. W. Borden, T. \& Stepleton, J. D., 1959. An improved method for the determination of lipase in serum. - Am. J. clin. Path. 31, 148-154. 